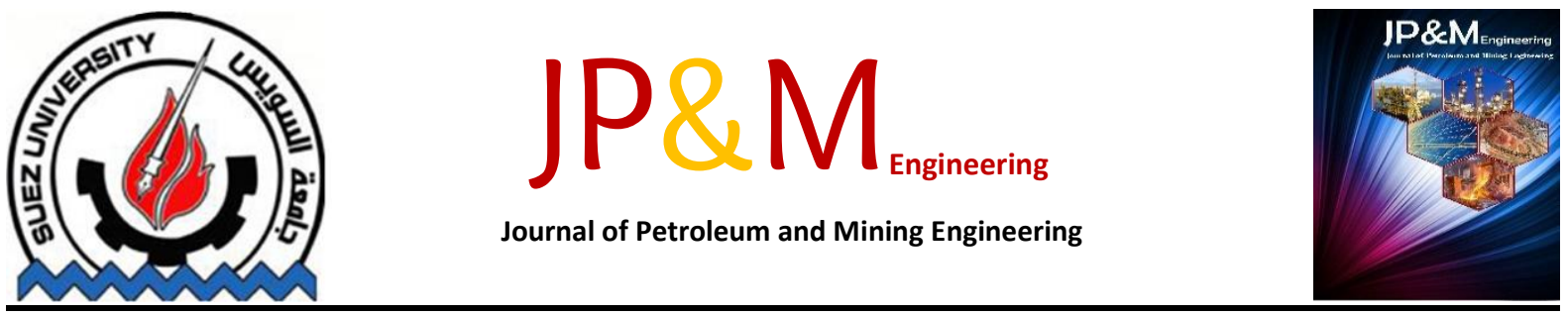

\title{
Sequence Stratigraphic Analysis of The Carbon-Siliciclastic Miocene Sediments, North Eastern Desert, Egypt
}

\author{
Hatem F. Hassan ${ }^{a^{*}}$ and Sarah M. Hany \\ ${ }^{a}$ Geology Department, Faculty of Science, Port Said University 42521, Egypt \\ ${ }^{b}$ Geology Department, Suez Canal University, Ismailia41522, Egypt
}

\author{
Keywords \\ Burdigalian; Langhian; Gharra; \\ Genefa; Siliciclastics- \\ carbonate; Sequence \\ Stratigraphy; Cairo-Suez \\ district Egypt.
}

\begin{abstract}
The depositional and stratigraphic studies of the Miocene sediments exposed at the north part of the eastern desert, clearly established. It is divided into two rock units, the lower siliciclastic one termed as Gharra Formation, representing the lower Miocene (Burdigalian) and upper carbonate, termed as Genefa Formation of Middle Miocene age (Langhian). The microfacies investigations of thirteen thin sections in the Gharra Formation revealed the presence of inner-shelf to intertidal lagoons facies whereas the microscopic investigations of twenty two thin sections from Genefa Formation revealed innershelf, middle neritic and outer shelf facies. The depositional sequence was initiated and developed as a result of the first advance of the Miocene Sea over the study area with type-1 Sb over the continental sediments of the Oligocene. Retrogradational parasequence are successively stacked within the LST, whereas the transgressive surface (ts) almost coincides with the stratigraphic contact between the Gharra and Genefa formations with a marked change in the parasequences geometry into retrogradationalaggradational nature with clear sea-level rise. By the Middle Miocene, a general sea level rise accompanied by deeper accommodation depositional setting due to tectonic subsidence, where relatively deeper marine facies started to deposits the Genefa Formation, just over the transgressive surface (ts). These sediments constitute the general transgressive system tract in the study area. It includes well-stacked retrogradationalaggradational parasequences mainly deposited within shelf zones.
\end{abstract}

\section{Introduction}

Siliciclastics-carbonate sequence has acquired an importance due to facies relationships and response to changes in relative sea level. It represents a transition zones between subtropical carbonate-dominated and temperate siliciclastic-dominated strata. Most of siliciclastic-carbonate setting setting inherit these settings due to tectonic event and paleotopography differences. The Miocene in north of Cairo, suez road is one of these transitional zones that forming a prominent and wide scenery of low hillocks sediments, well exposed at north of Cairo-Suez road (Fig.1) It stretches from east of Cairo up to the west of Great bitter lakes and constitutes a characteristic lithofacies of carbonate/siliciclastic facies that could be differentiated from other stratigraphic units. It consists of clasticdominated facies, termed as Gharra-Formation and upper carbonate- dominated facies of Genefa Formation Voluminous literature dealt with the Miocene based upon different fossil content rather than stratigraphic implications e.g. Sadek (1926, 1959, 1968); Macfadyen (1930), Cherif $(1966,1980)$, Abdallah and Abdel Hady (1966), Cherif and Yehia (1977) and Hamza (1992). Souaya (1961 \&1963), Metwalli (1963), Abdelghany \& Piller (1999), Mandic \& Piller (2001), Abdelghany (2002), Kroh \& Nebolisk (2003) and El Shazly (2011). Among these remarkable works, Ismail \& Abdelghany (1999) subdivided the Miocene rocks in Cairo- Suez Road into three rock units; Gharra, Sadat and Hommath formations and further identified 59 foraminiferal species which used in correlation between the studied sections due to poor evidence of correlation between these carbonate/siliciclastic sediments. The study of sedimentary facies and paleoenvironments of this area is undertaken by El Azabi (2000) who concluded that the Miocene succession in Sadat-Wadi Hagul, have special lithofacies characteristics that vary from adjacent basin as well as the Middle Miocene represent the reefal limestone of coral reef rimmed carbonate shelf. On the other hand, stratigraphic and sedimentary facies studies coupled with the role of rift and faulting, are the other aspect of 
interest, which dealt by Shukri \& Akmal (1953) Ghorab \& Marzouk (1965) and Hughes et al (1992). In this respect, Said (1962) suggested that, the rejuvenated tectonic movements (block faulting) are responsible for facies and thickness variations of the Miocene sediments. whereas Keheila (1990) Mentioned that the study of lateral and vertical distribution of lithofacies and paleoenvironments of the Miocene sequence in the Nile Delta and its eastern adjoining area enabled recognition of the three successive cycles of sedimentation, by the end of Oligocene, Early Miocene and Late Miocene-Early Pliocene. He (op.cit) added that, the proposed Miocene eustacy, when compared with the global eustatic sea level changes, showing that, the first and third transgressive cycles were controlled by global eustatic rises in the sea level whereas the second regressive event was related to local active tectonics. Purser and Philobbos (1993) summarized the tectonic events affected the sedimentation, formation of the Red Sea and the global changes in the Miocene sea level. They (op.cit) concluded that at the early part of the Miocene a general sinking occurred at the land causing the sea to advance across the Isthmus of Suez and Red Sea depression. Swezey (2009) used the term Gharra Formation to denote the Early Miocene sediments and attribute the dominance siliciclastic sediments to the tropical to subtropical climate rather than sea level rise. The aim was to study these rocks in their surface outcrops to enable better understanding their stratigraphic characterization, depositional environment and their sequence stratigraphic context.

\section{Materials and Methods}

The study area Fig. (1) is located North of Cairo-Suez road between longitude $31030 \backslash \mathrm{E} \& 32030 \backslash \mathrm{E}$ and latitude 300 $00 \backslash N \& 30030 \backslash N$. The studied surface sections include, Gabal Hamza and Gabal Um Qamar as composite section. Gabal Homira, El Rubiki section and Gabal Shabrawet Fig. (1). 90 samples were collected as a part of field work covering the carbonate/siliciclastic sediments of the EarlyMiddle Miocene age. The sedimentary facies constituting the Miocene sediments were examined for their thickness behavior, bed-contacts, bed-geometry pattern, characteristic sedimentary structures and their content of fossils and trace-fossils. A microscopic investigation for 35 thin sections representing the different examined Early-Middle Miocene lithofacies in the study area were determined according to Dunham (1962), Wilson (1975), Flügel (1982), and Tucker \& Wright (1990). While for the study of the siliciclastics microfacies, the work of Folk (1974), Pettijohn (1975), Pettijohn et al. (1987) are adopted.

\section{Results}

\section{Lithostratigraphy}

The rock units exposed in north of Cairo-Suez road could be subdivided into two formal rock units as discussed below

\section{Gharra Formation:}

The term Gharra Formation was first introduced by Said (1962) in Gabal Gharra, Cairo-Suez district to describe arenaceous and detrital limestone with shale and sandstone. Ghorab \& Marzouk (1965) used the term Gharra Formation to describe the Early and Middle Miocene sediments which are composed mainly of sandstone, mudstone with minor intercalation of sandy limestone. In the study area, Gharra Formation unconformably overlies Oligocene rocks (Gabal Ahmar Formation) and conformably underlies Genefa Formation of Middle Miocene age. It is encountered in all studied sections and composed of sandstone and shale or mudstone interbedded with minor sandy shale intercalations Fig. (4a). Sandstone in the studied sections may exhibit tabular planar Fig. (4b), trough cross bedding or load cast, somewhat bioturbated by Ophiomorpha Fig. (4c), Spongeliomorpha and serpulid worm tubes ichnofossil. On the other hand, shale intercalations may exhibit varicolored, yellowish, brown, and grey to greenish grey, occasionally gypsiferous. Gharra Formation, showing lateral variation in lithology as the sandstone beds become thinner or vanished toward southeast directions. It assumes different thicknesses; $13.8 \mathrm{~m}$ at Gabal Hamza, $12.8 \mathrm{~m}$ at Gabal Shabrawet, 5.6m at El-Rubiki section and $4.0 \mathrm{~m}$ at G. Homeira section. Its equivalents Fig. (3) along the Red Sea are Sadat formation (Abdallah and Abd El Hady, 1966), Gabal El Russas Formation (El Akkad and Dardir, 1966), Abu Gerfan Formation (Ghorab and Marzouk, 1967), Ranga Formation (Samuel and Saleeb-Roufaiel, 1977). Along the Gulf of Suez Gharra Formation equivalents to Nukhul Formation (NSSGS, 1974), Rudies Formation (NSSGS, 1974) but in Sinai Lower Rudies is the equivalent of Gharra Formation. Sidi Salem Formation is Gharra's equivalent in the north Delta embayment ( $\quad 600-1000 m$ thick). Whereas along Abu Roash-Fayum stretch (North Western Desert) both Gabal Khashab and Moghra formations represent the Early Miocene age (Said, 1990) and are equivalent to Gharra Formation in the study area.

The studied Gharra Formation is dated back to Early Miocene (Burdigalian) based upon the presence of faunal association, e.g. Flabellipecten burdigalensis (Lamarck), Pecten ziziniae Blanckenhorn Fig. (4d), Crassostrea gryphoides (Scholtheim) and Parascutella deflersi (Gauthier).

\section{Genefa Formation:}

Said (1990) and El Shazly \& Saber (1999) used the term Genefa Formation to describe the early Miocene sequence in. The later authors reported that Genefa Formation is mainly carbonate unit with small difference in its facies. Towards the east at the entrance of the Gulf of Suez, the Genefa grades into a grit- marl shale section which is named Hommath Formation. It is conformably underlain by Gharra Formation of Early Miocene age Fig. (4e). Lithologically, it is exhibited by limestone, sometimes sandy, chalky, intervend with clay, highly fossiliferous with corals, Echinoids and microfossils (Planostegina sp.), occasionally capped with buff to pinkish compact fossiliferous limestone Fig. (4g). It showing gradual thickness reduction toward the northwest as shown Fig. 2, except at G. Shabrawet Genefa Formation at Gabal Hamza \& Gabal Um Qamar composite section represent $13.8 \mathrm{~m}$, Gabal Shabrawet $36.6 \mathrm{~m}$, El-Rubiki section represent $16.3 \mathrm{~m}$ and Gabal Homeira represented by $20 \mathrm{~m}$ thickness. It is equivalent to lower part of Hommath formation Fig. 3 recorded at Sadat-Wadi Hagul stretch (Abdallah and Abd El Hady, 1966), and to the lower part of Gemsa formation (Ghorab and Marzouk, 1967), which extends along the western margin of the Gulf of Suez basin Fig. (3), also it equivalent to the deeper marine facies of the Gulf of Suez, Kareem formation (Oil company reportsNSSG, 1974), of Early Serravalian, and the lower part of Sarbout El Gamal (Late Burdigalian-Langhian) in Sinai 
(Ghorab and Marzouk, 1967). Although Genefa Formation is highly fossiliferous with Corals, Echinoids, bivalves, gastropod casts and molds, but due to amalgamated faunal association, age assignments represent a matter of controversy. Some authors extended the age of Genefa Formation to the early late Miocene (Tortonian). In the study area, due to the presence Crassostrea duverger (Cossmann and Peyrot), Equipecten sub-malvina Blanckenhorn. In addition to internal molds of Dosina orbicularis (Agassiz), Periglypta ambigua (Rovereto) Fig. (4f), Apolymetis lacunose (Chemnitz) and Spondylus crassicosta Lamarck dates the Genefa Formation to Middle Miocene (Langhian age). The presence of Planostegina costata (d'Orbigny) in Gabal Shabrawet section also confirm the Langhian age of Genefa Formation in the study area.

\section{Discussion}

The microfacies investigations of thirteen thin sections representing Gharra Formation revealed the presence of the following microfacies associations:

\section{Microfacies types and facies interpretation:}

Eight microfacies associations were described from the Gharra Formation and grouped into two facies associations representing sub environments.

\section{1-inner-shelf facies}

\section{a-Mud-shale microfacies association}

This microfacies association is recognized in the lower, middle and upper parts of the Gharra Formation at Gabal Hamza (samples; $\mathrm{Hz} 3, \mathrm{~Hz} 7$ and $\mathrm{Hz} 19$ ). It consists of a common light brown mud, forming the total bulk of the association. Little amount of very fine to silt quartz grains are seen throughout the mud facies as small pockets. Rare skeletal, ill-defined bioclasts are sometimes recorded and common clay pellets of darker colors are observed. This association provides deposition in relatively quiet low energetic setting. Deposition within shallow marine inner-shelf restricted lagoons or semi- closed bays is suggested for this lithofacies. In addition, these shallow marine settings were receiving terrestrial stream-loads in addition representing the transgressive marker beds, due to the presence of rhodolith fragments (Bassi and Nebelsick, 2010; Bassi et al., 2009; Manker and Carter, 1987; Nalin et al., 2008 and Johnson et al. 2011).

\section{b-Dolomitized microsparite/Dolomitized grainstone}

This microfacies association is encountered in Gabal Hamza, at the middle part of Gharra Formation (sample; $\mathrm{Hz} 15$ ). It is represented by pale yellow, hard, thinly bedded limestone, commonly represented by successive beds having laterally extensive sheet geometry. Gypsiferous bands are traversing the association body Fig. (5a). Petrographically, these limestones are composed of a few allochems, only represented by scattered shellhashes (pectinids?) seen as faint ghosts due to the intense dolomitization. These allochems are embedded in microsparite cement, which is intensely replaced in many parts by both fine and coarse-grained zoned dolomite rhombs. This microfacies represents deposition in shallow warm marine water far from the reach of detrital loads. Deposition within inner-shelf shallow bays is suggested. These bays were directly connected to the open-sea where the biota can pass freely into the shallow bays. This association can be correlated to the SMF 17/18 and FZ 7/8 of (Wilson, 1975 and Flügel 1982).

\section{c-Fossiliferous quartz arenite}

This microfacies is encountered in the middle and upper parts of Gabal Hamza (samples: Hz10, Hz18 and $\mathrm{Hz24}$ ) at the middle parts of Gharra Formation in Gabal EI Rubiki (samples R6 and R7). In the field lithologically it is represented by yellow to yellowish brown, hard to medium hard sandstone, slightly gravelly, characterizing by both small-scale trough and herring-bone crossstratifications, sometimes extensively bioturbated with strong animal burrows. Petrographically, it consists of abundant rather sorted, coarse to medium quartz grains ranging in size from 1.0 to $0.4 \mathrm{~mm}$ Fig. (5b). The majority of the quartz grains are of monocrystalline varieties, however, the polycrystalline ones are rarely encountered and exhibit undulose extinction. Most grains are subangular usually display point grain-contact. The grain boundaries are coated with thin iron oxide rim. Unaltered alkali-feldspar grains are also present. Bioclasts of different molluscan shell debris, echinoid spines and coral patches are encountered. The iron stains usually masks most of the rock components and constitutes small patches scattered in thin sections. All these components are cemented by a little amount of muddy matrix bonded with minor calcareous cement. The field and petrographical characteristics of this facies suggest deposition as successive small-scale sinuous-crested, sand-waves, commonly organized within low energy streams (Harms et al, 1975). Moreover, the dominance of calcareous muddy matrix together with extensive strong animal-burrows provides deposition within a shallow warm coastal zone of marine shore-line sub environment. The present facies was accordingly, deposited as successive siliciclastic loads derived by supracrustal less energetic streams into an estuarine tidal lime-mud flat flourished by a faunal community. This facies represents the Early Miocene "estuary" receiving appreciable siliciclastic input. It marks the start of an Early Miocene sea-level rise and formation of a low stand phase by the deposition of the Gharra Formation.

\section{d-Sandy biosparite/ Sandy grainstone}

This microfacies association is composed of yellow, hard, compact fossiliferous limestone, encountered in the upper part of Gharra Formation, in El-Rubiki section (sample R8) and in Gabal Hamza (sample Hz27). It is composed of dominant large bioclasts deposited with (10-20\%) detrital quartz grains. The bioclasts include large fragments of pelecypods and gastropods commonly display ill defined boundaries and have internal fibrous structure. Quartz grains range from coarse to medium in grain size, commonly subrounded to rounded and display weak undulose extinction. Rare rounded detrital glauconite grains are occasionally recorded between the rock components. The rock constituents are hardly lithified by coarse crystalline sparite and sparry calcite that undergo clear dolomitization. Dolomite rhombs are variable in size, occasionally zoned Fig. (5c).This microfacies suggests deposition within a shallow marine depositional setting having warm water and adequate life possibilities that enabled the different encountered organisms to survive and flourish. However, this depositional realm is not too far from sources of detrital sand grains (quartz and glauconite). Deposition within inner-shelf shallow bays, situated close to shelf sand bars is interpreted for this microfacies. These sand bars supplied the shallow bays by the detritals encountered, whereas the different organisms were derived from the open sea through inlets connecting the bays. This 
microfacies can be correlated to the SMF 12 and FZ 6 of Wilson (1975) and Flügel (1982).

\section{2-intertidal lagoons facies}

\section{a-Glauconitic quartz arenite}

Lithologically, it represented by thinly bedded yellowish green sandstone, encountered in the middle and upper parts of Gharra Formation at Gabal Hamza (samples; $\mathrm{Hz} 12$ and Hz26). Petrographically, it is mainly built of medium grained quartz sands forming about $40 \%$ of the rock body. Rounded glauconite grains are very frequent and constitute $50 \%$ of the rock. Quartz grains are well sorted, rounded to subrounded, and of monocrystallinetype with even to slight undulose extinction. Glauconite grains Fig. (5d) are of fine to medium sand size (0.1$0.4 \mathrm{~mm}$ ). These components are cemented with fine sparite calcareous cement. Iron oxides commonly stain the facies components and act as additional weakly cementing materials. Rare serpulid worm tubes Fig. (5d) of elliptical to circular outlines with concentric ferrigenous laminae, filled with quartz grains may also encountered in this association. The common presence of glauconite grains provides locally reducing media within generally oxidizing shallow marine setting (Reineck, 1972). The absence of any fossil remains together with the deposition of carbonates and some evaporites all assume low energetic depositional setting with relatively high salinity and warm water. However, this setting was receiving frequent load of detrital sands. This microfacies was possibly deposited within intertidal lagoons surrounded by coastal sand bars. This microfacies can be correlated to the SMF 4, FZ 1/3 of (Wilson, 1975 and Flügel 1982).

\section{Genefa Formation}

The microscopic investigations of twenty two thin sections from Genefa Formation revealed the following microfacies:

\section{1-inner-shelf facies}

\section{a-Ferruginous quartz arenite}

This microfacies is encountered in the middle part of Genefa Formation at El-Rubiki section (sample: R15). Lithologically, it is represented by yellow to yellowish brown, hard fossiliferous sandstone with many cavities. Petrographically; it is essentially composed of medium to very fine $(0.28-0.08 \mathrm{~mm})$ quartz grains. The majority of these grains are of monocrystalline type with even and rarely undulose extinction. The polycrystalline ones are rarely encountered and exhibit variable undulose extinction. Most of the grains are subangular to subrounded with rare point contact grain boundaries coated with thin iron oxide Unaltered plagioclase grains are also encountered. Rare glauconitic pellets and lithic fragments are also present. The binding material is represented by argillaceous matrix strongly masked with secondary ferruginous materials of deep brown color. This microfacies was possibly deposited within shallow bays of the inner-shelf. This microfacies can be correlated to SMF 4, FZ 1/3 of (Wilson, 1975 and Flügel 1982).

\section{b-Dolomitic quartz arenite}

This microfacies is recognized in the lower part of Genefa Formation in Gabal Hamza (sample Hz28) and El Rubiki section (sample R10), represented by yellow hard sandstone. Petrographically, it consists of coarse to fine $(0.90-0.15 \mathrm{~mm})$ quartz grains $(90 \%)$, mostly of monocrystalline type, some with even to slightly wavy extinction. Rare polycrystalline grains are encountered with strong undulose extinction. The quartz grains are subrounded, moderately sorted and display point and line grain-contacts. Grain boundaries are sometimes corroded by the surrounding matrix. Bioclasts are represented by $10 \%$ of bivalve shell fragments together with echinoid spines, some foraminiferal tests and red coralline algal patches. The binding material is muddy matrix, partly undergoes dolomitization. Dolomite rhombs replace some components such as shell fragments. This microfacies was possibly deposited within shallow bays of the inner- shelf. This microfacies can be correlated to SMF 4, FZ 1/3 of (Wilson, 1975 and Flügel

1982).

\section{c-Dolomitic algal biosparite/ Dolomitic fossiliferous packstone}

It is encountered in the upper part of Genefa Formation at Gabal Homira (samples: $\mathrm{Hm} 8, \mathrm{Hm} 10$ ) and ElRubiki section (sample R22). It is composed of yellowish brown to dark brown, hard dolomitic limestone. Petrographically, it is mainly built up of coralline red algae that form about $50-70 \%$ of the rock contents. They are mostly micritized with well preserved internal organic microstructures. Large molluscan shell fragments are present and exhibit fibrous microstructure Fig. (5e). Terrigenous materials are rarely encountered and are mainly represented by quartz grains that decrease upward in the succession. The binding material is neomorphosed and dolomitized sparite. This microfacies was possibly deposited in the shallow parts of the inner shelf zone rich enough of different life necessities. This facies can be correlated to SMF 21, FZ 8 of (Wilson, 1975 and Flügel 1982).

\section{2-middle neritic facies}

\section{a-Dolomitic biosparite/Dolomitic boundstone}

This microfacies association is only encountered in Genefa Formation at Gabal Shabrawet (samples; Sh9, Sh13, Sh16 and Sh18) and Gabal Hamza (sample Hz30). It represents the upper part of Genefa Formation. It is composed of fossiliferous, hard, chalky and buff limestone. Petrographically, it mainly consists of bioclasts including different types of corals, shell fragments (Ostrea and Pecten), foraminiferal tests (Planostegina costata) in addition to Ostracods carapaces, completely filled with sparite. Terrigenous materials are not common and are mainly represented by quartz grains. The binding material is neomorphosed and dolomitized micrite Fig. (5f). Dolomitization obliterate most of the shell fragments of bivalves. This microfacies was possibly deposited in the shallow part of middle neritic environment. This can be correlated to SMF 21, FZ 8 of (Wilson, 1975 and Flügel 1982).

\section{b-Sandy algal biosparite/Sandy algal grainstone}

This microfacies is only recorded in at El-Rubiki section (Sample R13). It represents the middle part of Genefa Formation. Petrographically; it is built up mainly of shell fragments and red coralline algae that consisting 
about $80 \%$ of all components. Algae represented by both Lithophyllum sp. and Lithothamnium sp. Fig. (5g) whereas the shell fragments represented by bivalve shell. Rare pellets also encountered. Terrigenous materials represented by quartz grains (10\%) of small size and rounded grains. The binding material is neomorphosed sparite. This microfacies was possibly deposited in the shallow part of middle neritic environment. This can be correlated to SMF 2, FZ 1/3 of (Wilson, 1975 and Flügel 1982).

\section{3-outer shelf facies}

\section{a-Dol-biosparite/ Algal boundstone}

Lithologically; it is represented by fossiliferous dolomitic limestone encountered in the upper part of Genefa Formation at El-Rubiki section (sample R19) and G. Shabrawet (samples: Sh7, Sh8, Sh15 and Sh22). Petrographically, it is built of coralline red algae as a main component forming about $40-50 \%$ of the total facies volume. They are mostly micritized and their internal microstructures are masked due to severe dolomitization. Large benthic-forms of Planostegina costata are frequently encountered, especially at G. Shabrawet (sample Sh22; Fig. (5h)). Terrigenous materials are rarely encountered, mainly represented by clayey material. The binding material consists of neomorphosed dolomitized sparite. This microfacies was possibly deposited in shallower part of an outer shelf environment most likely reef build-up. This facies can be correlated to SMF 5, FZ 4 of (Wilson, 1975 and Flügel 1982).

\section{b-Sandy dol-biosparite/Sandy dolomitic grainstone}

Lithologically; it is represented by fossiliferous marly limestones of the upper part of Genefa Formation at G. Homira (samples; $\mathrm{Hm} 6$ and $\mathrm{Hm} 9$ ). Petrographically, it is mainly built up of different types of bioclasts including, red coralline algae forming about $20 \%$. In addition to large bryozoans clasts forming about $25 \%$, of the main components. Coarse grained quartz are encountered as the common terrigenous materials scattered between the rock components. The binding material is calcareous sparite cement that undergoes high dolomitization by zoned medium-sized dolomite rhombs. This microfacies was possibly deposited in shallower part of outer shelf environment. It can be correlated to SMF 11/18, FZ 7/8 of (Wilson, 1975 and Flügel 1982).

\section{c-Biosparite/ Algal grainstone}

Lithologically, it is represented by fossiliferous clayey limestone present at the upper part of Genefa Formation at G. Homira (sample: Hm7) and Gabal Shabrawet (samples: Sh20 and Sh21). Petrographically, it is built up of different types of bioclasts fragments including foraminifera, echinoids and red coralline algae. All these components are cemented by micritic matrix that are partially neomorphosed to coarse sparite cement. This microfacies was possibly deposited in an outer shelf environment. This facies can be correlated to SMF 12, FZ 8/7 of Wilson (1975) and Flügel (1982).

\section{Depositional Trends of the Early-Middle}

\section{Miocene Platform:}

The examined Miocene platform sediments, north of Cairo-Suez Road could be differentiated into two main units; lower clastic-dominated unit and upper carbonatedominated unit:-

\section{Clastic-dominated unit}

This unit is represented by Gharra Formation, consisting of repetitive parasequences each of which consist of cross-bedded sandstones followed by thinly laminated mudstone/shale. The cross bedding is mainly of planar, trough and herring-bone types. The upper part of this facies is mainly built of sandy limestone rich in oyster bank intercalated with mudstone and sandstone near the top, both of mudstone and sandstone are fossiliferous with pectinids and Parascutella sp. in addition to the presence of coralline serpulid worm tubes. It is worth mentioning that such clastic rich sedimentation regime decreased northwards. Moreover, the uppermost part of Gharra Formation in Gabal Hamza composed of thin bedded glauconitic sandstone whereas in other localities it contains mudstone/shale that is devoid of macrofossil and contain small benthic forams such as Miogypsina, Operculina in addition to Amphistegina. The depositional trends Fig. (6) encountered in this clastic dominated unit vary from intertidal foreshore facies (intertidal estuarine, intertidal lagoons) to shallow shelfbays facies, which expresses the deepest bathymetrical zone during the deposition of the present unit.

\section{Carbonate-dominated unit}

This sedimentary unit consists mainly of dolomitic limestone and reefal limestone of Genefa Formation. The limestones are highly fossiliferous with coralline red algae, Amphistegina sp., Miogypsina sp., Planostegina and Oysters. The depositional trends of this unit encompass different relatively deeper marine zones than the lower ones of Gharra Formation. The present marine environments vary from shallow shelf bays to inner, middle and outer neritic zone Fig. (6) with the dominance of reef build-up mass in the eastern parts of the study area.

\section{Sequence stratigraphy}

The detailed field and laboratory studies made for the Miocene sediments in the study area have indicated that both Gharra and Genef formations constitute one incomplete depositional sequence. This depositional sequence was initiated and developed as a result of the first advance of the Miocene Sea over the study area.

\section{Sequence boundaries}

The present depositional sequence encompassing Gharra and Genefa formations(Fig. 7) rests unconformably over the continental sediments of the Oligocene Gabal Ahmar Formation. Accordingly, this sequence boundary is of "Type-1" of Vail et al (1977). All of the recorded sequence boundaries in the studied 
sections represent tectonically controlled sequence boundaries of SB 1 type. The close of the Oligocene witnessed a long phase of subaerial emergence accompanied by marked activity of continental depositional systems, especially in the northeastern parts of Egypt including the study area. These conditions permitted the present type- 1 boundary to develop and form the base of the Gharra/Genefa depositional sequence. This unconformity surface matched with "Burdigalian-End Aquitanian Unconformity" (Guiraud et al, 2005)

\section{Low-stand System Tract (LST):}

With the first rise of the Early Miocene Sea over the northern territories of the Egypt, northeastern parts, including the study area, started to be submerged under shallow intertidal foreshore. These conditions continued all the time span of Gharra Formation, forming the low-stand wedge, that pushed its way southwards over the northern Egypt. Retrogradational parasequences represent fining upward sequence that started with high energetic fossiliferous quartz arenite sandstone that passing basin ward into inner-shelf shale/mudstone facies. Which are successively stacked within the given tract including tidal flat sediments, intertidal lagoonal facies and estuarine sediments.

However, the deposition of the tract was almost terminated by the deposition of the Sandy biosparite, Sandy Grainstone microfacies association within shallow shelf realm.

\section{Transgressive Surface (ts):}

This depositional surface is recorded all-over the study area. It marks the actual widespread marine invasion submerging the entire area. The present transgressive surface (ts) almost coincides with the stratigraphic contact between the Gharra and Genefa formations. The marked change in the parasequences geometry into retrogradational-aggradational nature with clear sea-level rise accompanied with the deposition of inner-outer shelf facies Fig. (6) instead of the shallow foreshore sediments below of LST, mark the present transgressive surface. The age of this transgressive surface (ts) can be correlated to the earliest Middle Miocene age.

\section{Transgressive System tract (TST):}

By the Middle Miocene, a general sea level rise accompanied by deeper accommodation depositional setting where relatively deeper marine facies started to deposits the Genefa Formation, just over the transgressive surface (ts). These sediments constitute the general transgressive system tract in the study area. It includes well-stacked retrogradational-aggradational fining upward parasequences mainly deposited within shelf zones. The deposition started with the deposition of Ferruginous quartz arenite and Dolomitic quartz arenite microfacies association within the shallow shelf bays of the middle Miocene marine transgressive phase directly following the transgressive surface (ts). The continuous sea-level rise over the northern parts of
Egypt, including the study area, results in the deposition of successive aggradational sequences within innermiddle neritic facies with the development of reefal build-up masses (Dol-biosparite, Algal Boundstone microfacies association) in different parts along the examined Middle Miocene platform. The sediments of Sandy dol-biosparite, Sandy dolomitic Grainstone and Biosparite, Algal Grainstone microfacies association interpreted as outer shelf facies toward the top of Genefa Formation represent the deepest sedimentary facies in the present transgressive systems tract (TST). The top of these facies could represent the maximum flooding surface ( $\mathrm{mfs}$ ) of the present depositional sequence, however this can not stated here with absolute certainty since the top of Genefa Formation is erosional surface. However, the exact position of the maximum flooding surfaces ( $\mathrm{mfs}$ ) could not be too high of the suggested location. The non occurrences or non deposition of the above mentioned upper part of the sequence may be attributed to the fact that a phase of uplift had occurred at the region adjacent to the Red sea between 13.8 and $5 \mathrm{Ma}$ (Middle to Late Miocene) time (Bohannon et al., 1989).

\section{Conclusions}

The marine Miocene carbonate/ siliciclastic sediments exposed at north of Cairo-Suez road is a transgressive sequence that unconformably underlain by the Oligocene continental sediments of Gabal Ahmar Formation. It encompassing the Burdigalian siliciclastic Gharra Formation that conformably overlain by the langhian carbonate Genefa Formation. The study of microfacies analysis revealed that the examined Miocene platform sediments, north of Cairo-Suez Road could be differentiated into two main units;

\section{Clastic-dominated unit}

This unit is represented by Gharra Formation and consists of repetitive parasequences each of which consist of cross-bedded sandstones followed by thinly laminated mudstone/shale and capped with sandy limestone rich in oyster bank intercalated with mudstone and sandstone near the top. The depositional trends encountered in this clastic dominated unit vary from intertidal foreshore facies (intertidal estuarine, intertidal lagoons) to shallow shelf-bays facies, which expresses the deepest bathymetrical zone during the deposition of the present unit.

\section{Carbonate-dominated unit}

This sedimentary unit consists mainly of dolomitic limestone and reefal limestone of Genefa Formation. The limestones are highly fossiliferous with coralline red algae, Amphistegina sp., Miogypsina sp., Planostegina and Oysters. The depositional trends of this unit encompass different relatively deeper marine zones than the lower ones of Gharra Formation. The present marine environments vary from shallow shelf bays to inner, middle and outer neritic zone with the dominance of reef build-up mass in the eastern parts of the study area. The depositional sequence was initiated and 
developed as a result of the first advance of the Miocene Sea over the study area with type-1 SB over the continental sediments of the Oligocene. Retrogradational parasequence are successively stacked within the LST, whereas the transgressive surface (ts) almost coincides with the stratigraphic contact between the Gharra and Genefa formations with a marked change in the parasequences geometry into retrogradationalaggradational nature with clear sea-level rise. By the Middle Miocene, a general sea level rise accompanied by deeper accommodation depositional setting due to tectonic subsidence, where relatively deeper marine facies started to deposits the Genefa Formation, just over the transgressive surface (ts). These sediments constitute the general transgressive system tract in the study area. It includes well-stacked retrogradationalaggradational parasequence mainly deposited within shelf zones.

\section{References}

[1] Abdallah, A. M M. and Abd El Hady, F. M. 1966, Geology of [2] Abde|ghany O. \& Piller, E. W. W. 1999 Biostratigraphy of

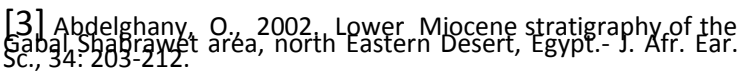

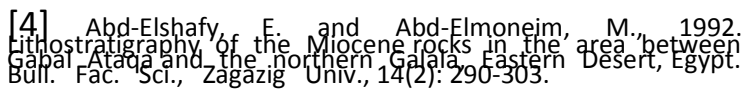
[5] Bassi, D.r. Nebelsick, J.H. 2010. Components, facies and

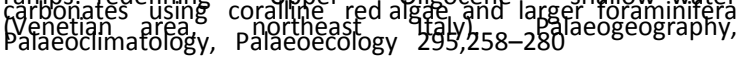
[6] Bassi, D.' Nebelsick, J.H. Checconni, A. Hohenegger, J., Iryu,

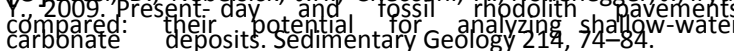

[7] Bohannon, R.G. Naeser C.W. W Schmidt, P. L Zimmermann

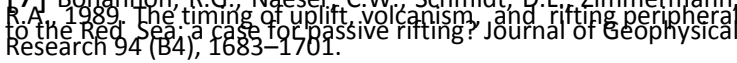

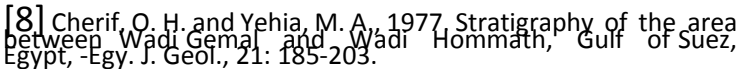
[9] Cherif, O.H. ${ }^{1966}$ The Geology of the Sadat area, Southwest [10] Cherif o . H. 1980 Remarques sur l'utilisation des

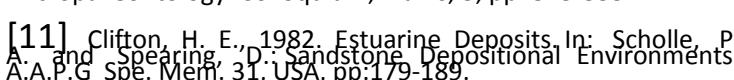

[12] Darwish, M. and El Azabi, M. H ${ }_{1}$ 1993. Contributions to the [13] Dunham, R. J. 1962. Classification of carbonate rocks

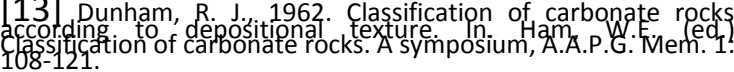

[14] El Akkad, S. E. and Dardir A, 1966. Geology of the Red Sea

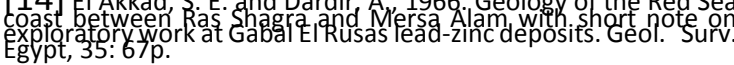

[15] El Azabi, M H Hi, 2090 Sedimentary facies,

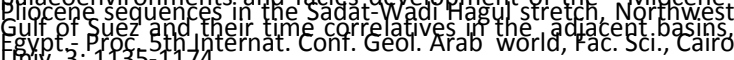

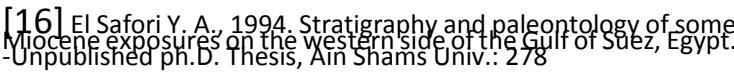

[17] El Shazly, S. H. and Saber, S. G. 1999 . Facies and

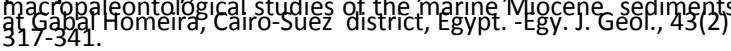

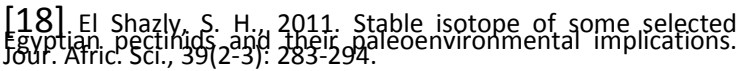

[19] Flügel,E., 1982. Microfacies analysis of limestone. -Springer [20] Felkilk, R.L.', 1974. Petrology of Sedimentary Rocks: Austin, TX,

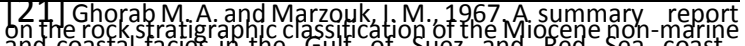

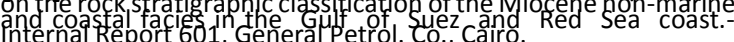

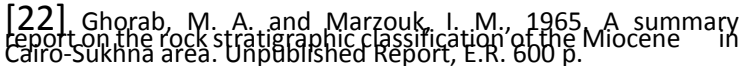
[23] Guiraud, R. Bosworth, W. Thierry' J. Delaplanque, A. [24] Hamza, F. H 1992 Contribution to the Neggene nnv., Earth'sci. Ser.,

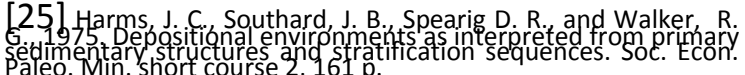
[26] Hassan, M.M. Omran M.A. 1991 Stratigraphy and

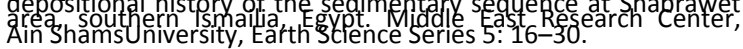

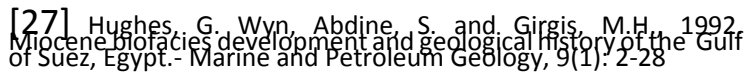

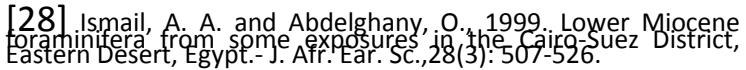

[29l.Johnson, M. E. da Sjlva, C. M., Santos, A, Gudveig Baarli, B,

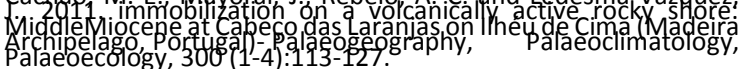

[30] Keheila E E 1990 Miocene facies models,

[31] Kroh, A. and Nebelsick, J. H, 2003. Echinoid assemblages as

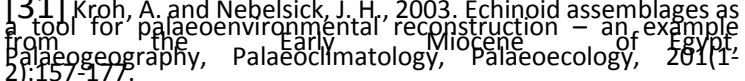
[32]. Macfadyen, W.A. 1930. Miocene foraminifera from the [34] Manker, JPP Carter. B.D.' 1987 . Paleocology and

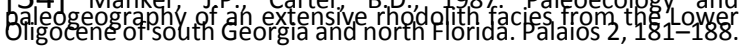

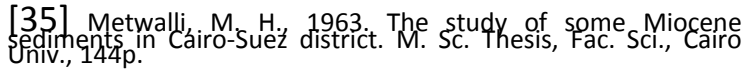

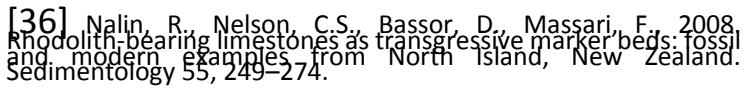

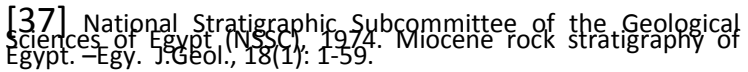
[38] Pettiiohn, F. J 1975. Sedimentary rocks. Harper and Row,

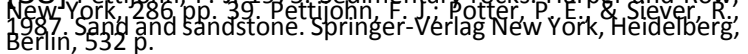

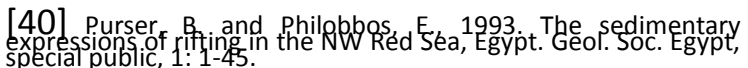
[41] Reineck, H. E., 1972. Tidal flats; SEPM Spec. Publ. 16: 146[42] Sadek, A., 1968 . Contribution to the Miocene stratigaphy

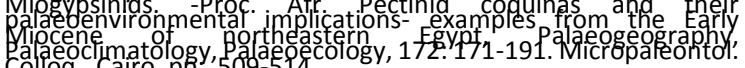

[43] Sadek, H, 1926. The geography and geology of the district [441],Sadek, H.ej1959. The Miocene in the Gulf of Suez region [45] Said, R., 1962. The Geology of Egypt. -El Sevier, 377p. [46] Said, R., 1990. The Geology of Egypt. - Balkema, Rotterdam

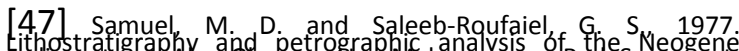
seypt. -Beitr. Lur Lithologie, Freiburg. Forsch.'323(c): $47-56$. [48] Souaya F. J 1961. Contribution to the study of Miggypsina
505.

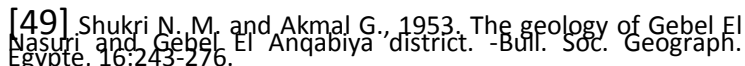

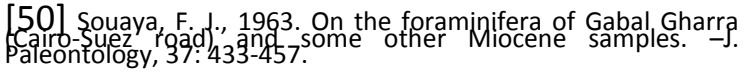

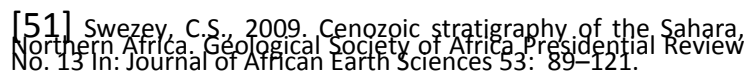
[52] Tucker,M.E. Whright, V.P., 1990. Carbonate Sedimentology. [53] Vail P. R. Todd R. G and Sangree, J.B 1977. Seismic

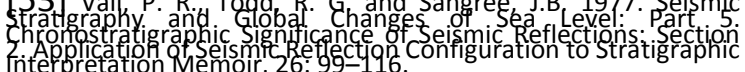




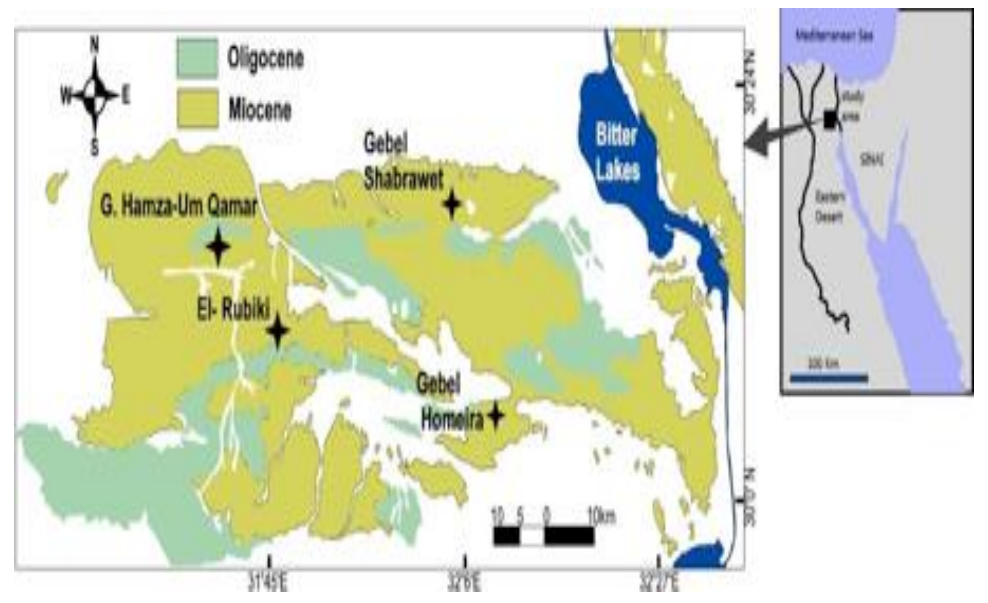

Figure 1 Location and Geologic map of the study area.

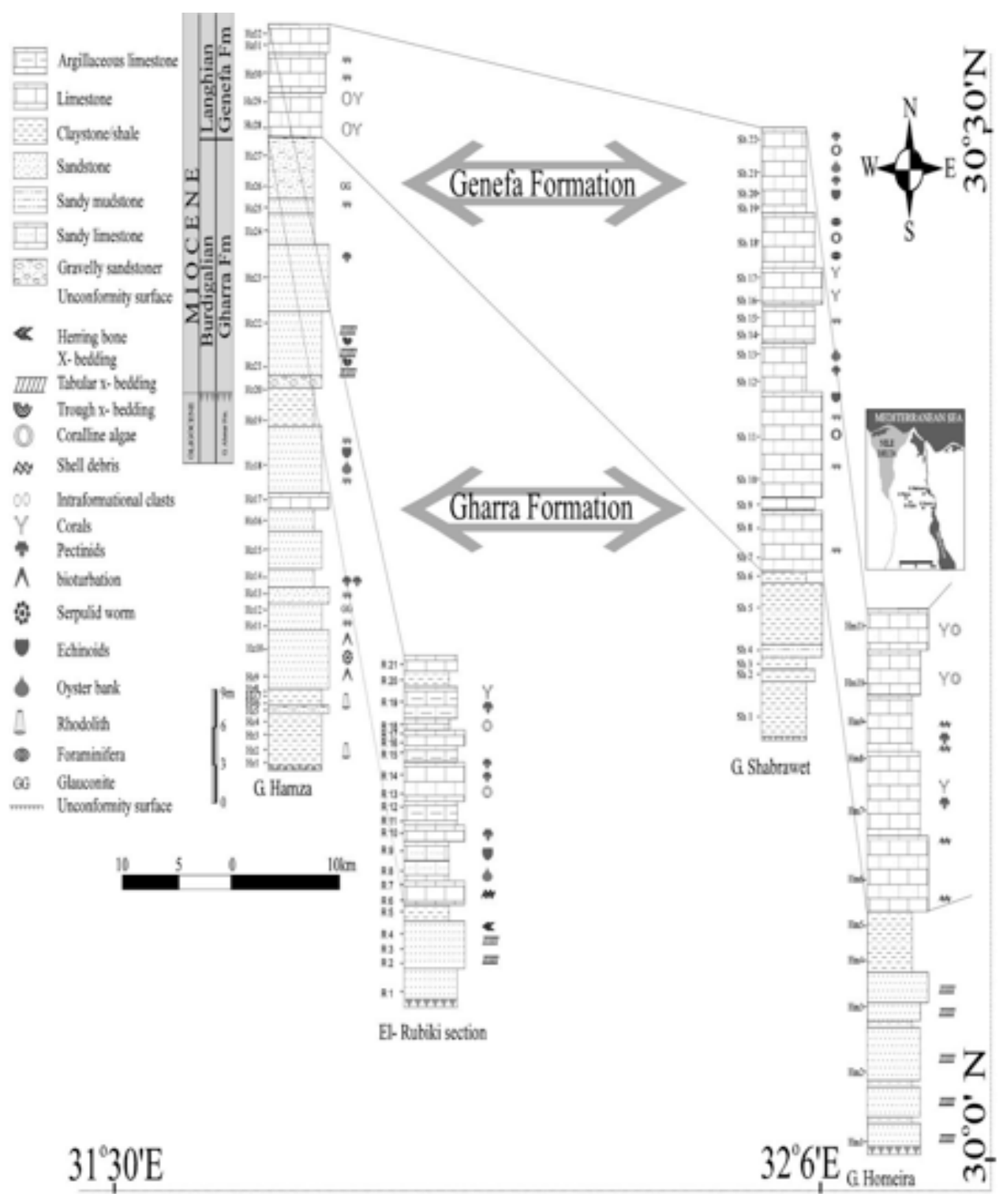

Figure 2. A litho-correlation diagram representing the simulating position of the studied sections

and regional distribution of the Miocene rock units in the study area. The top of Gharra Formation is taken as a general datum. 


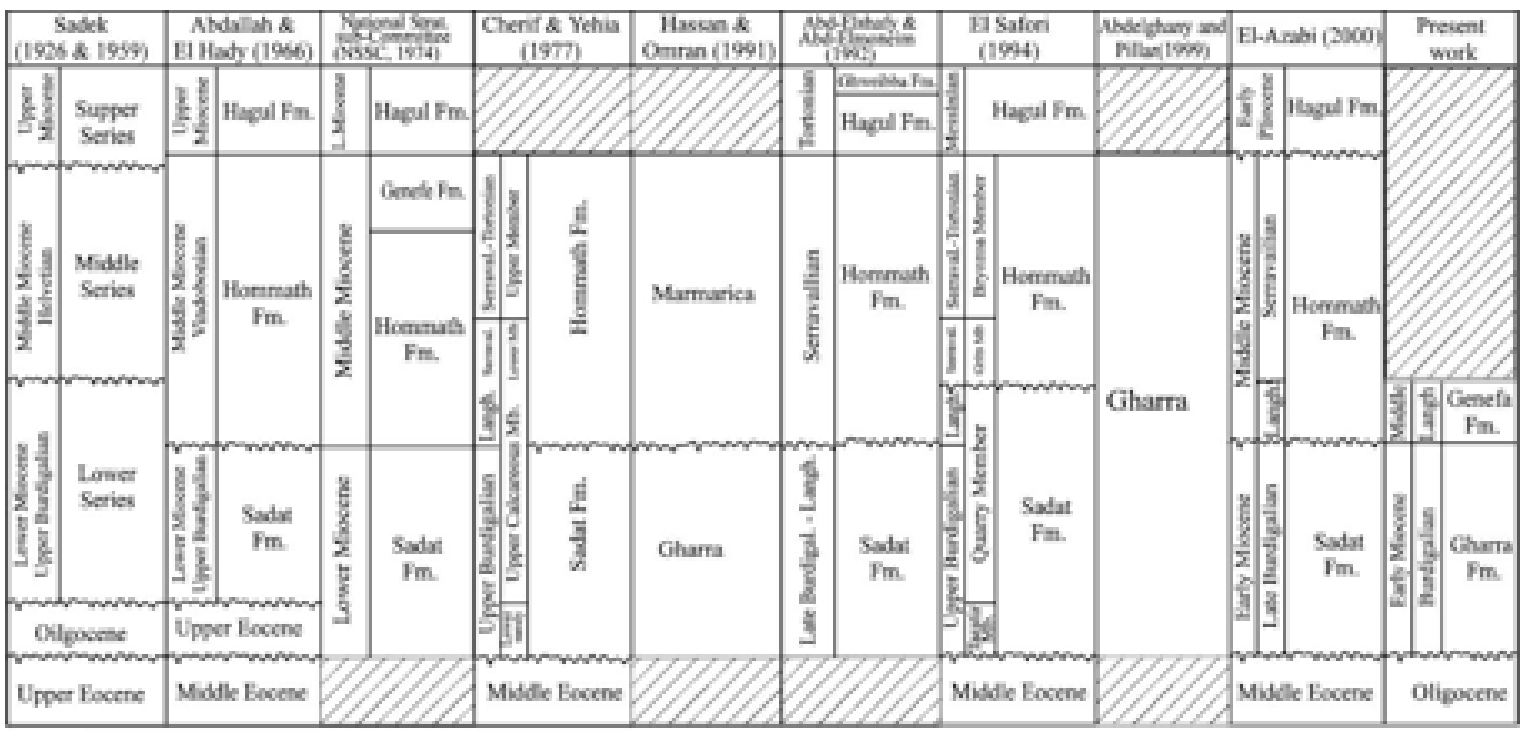

Not tecorded nom Unocenfoemity surface

Figure 3. Correlation chart of the Miocene rock units in the study area with some their equivalents in Egypt.
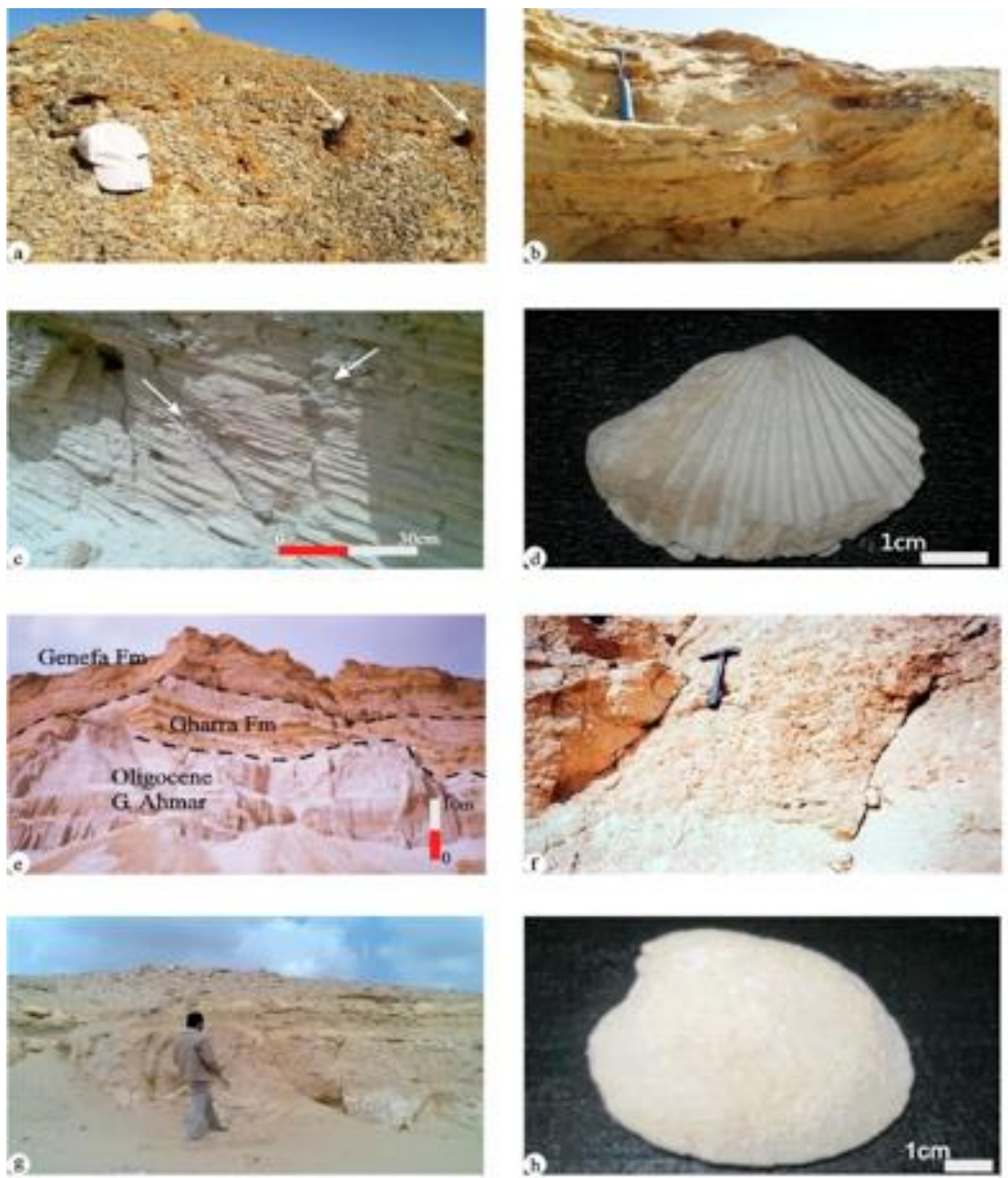

Figure 4. a; Highly fissile shale with long ferrigenous concretions (Rhodolith) (arrows), Gharra Formation, Gabal Hamza. b; Small scale, open trough cross- bedded sandstone, bioturbated and fossiliferous, Gharra Formation, Gabal Hamza.

c; Ophiomorpha ichnofossil (arrows) obliquely cut through the tabular planar cross-bedding dominated at Gharra

Formation, $d$; Pecten ziziniae Blanckenhorn righ valve, external view, Early Miocene, Gharra Formation, El-Rubiki section e; Field relationship between Oligocene Gabal Ahmar Formation, Gharra and Genefa formations, view looking to $S$ 
30oW, G. Homeira section, f; Corraline limestone, Genefa Formation, G. Shabrawet section., g; Buff to pinkish compact fossiliferous limestone Upper part of Genefa Formation, El- Rubiki section and $h$; Peryglypta ambigua (Rovereto), left valve, internal mold, Middle Miocene, Genefa Formation, Gabal Homeira section.
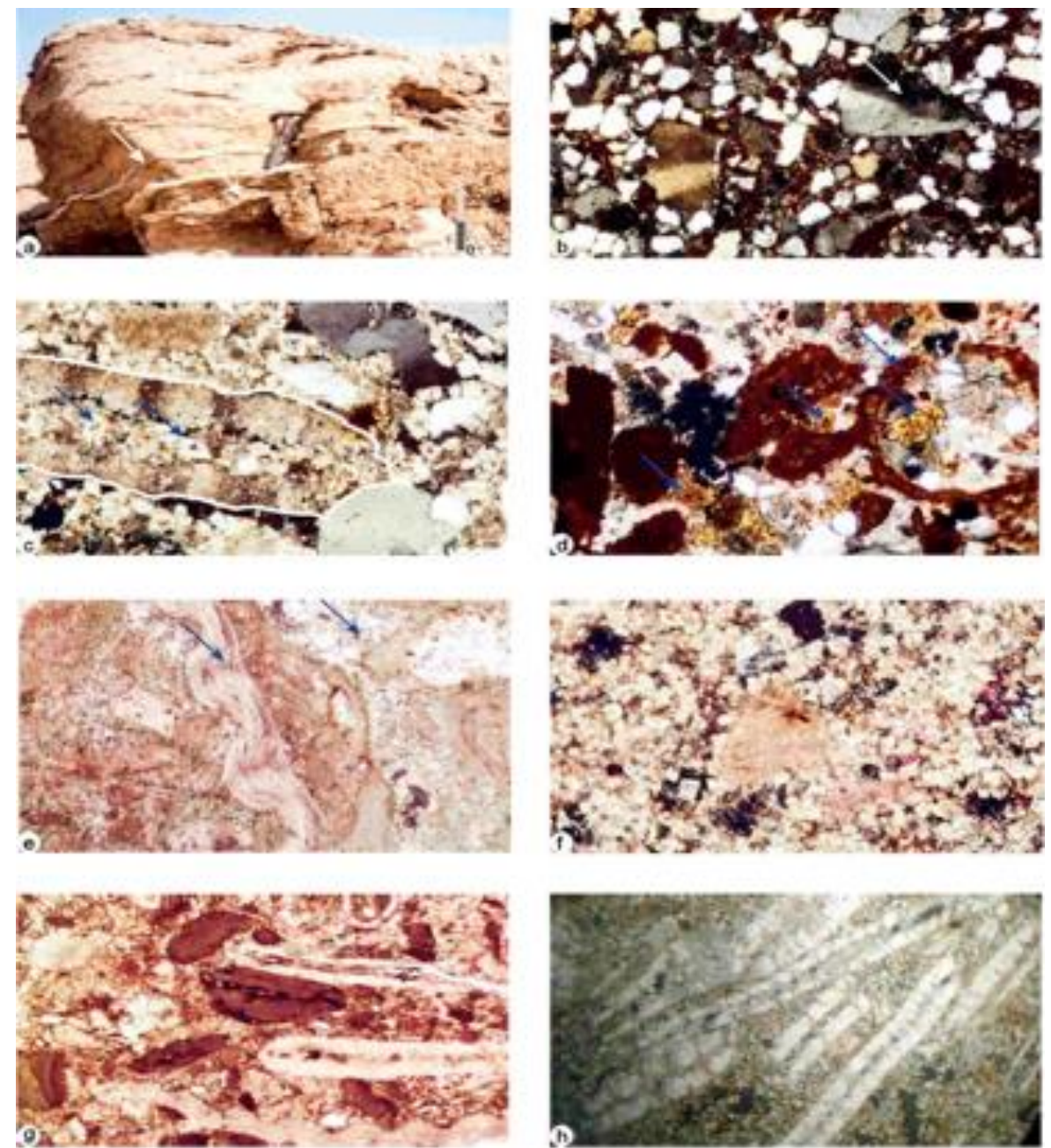

Figure 5.

a; Gypsiferous bands (arrows) are traversing the mud-shale lithofacies

b; Microphotograph showing the poorly sorted quartz-grains of the fossiliferous quartz arenite microfacies, sample Hz18, Gabal Hamza section, Gharra Formation; X.P.L., (25X).

c; Zoned dolomite crystal (blue arrows) filling and surrounded the large shell fragment (outlined); Sandy biosparite microfacies; sample R8 El Rubiki section; Gharra Formation; X.P.L. (100X).

d; Ferrigenous serpulid worm tube (blue arrows) filled with quartz grains and embedded in calcareous cement;

Glauconite calcareous quartz arenite microfacies; Sample Hz12; Gabal Hamza section; Gharra Formation; X.P.L. (25X). e; Internal fibrous microstructure (white arrow) of shell fragments (Ostrea sp.) in dolomitic sparite cement (black arrow); Dolomitic algal biosparite microfacies; Sample Hm10; Gabal Homira section; Genefa Formation; X.P.L. (25X). f; Stained euhedral dolomite rhombs in dolomitic sparite cement; Dolomitic biosparite; Sample R19; El Rubiki section; Genefa Formation; X.P.L. (100X).

g; Different forms of red coralline algae (Lithophylum and Lithothamnium) and rare pellets embedded in sparite cement; Sandy algal biosparite microfacies; Sample R13; El Rubiki section; Genefa Formation; P.P.L. (25X).

h; Planostegina costata (d'Orbigny) embedded in dolomitic micritic cement; dol-biosparite microfacies; Sample

Sh22; Gabal Shabraweet section, ; Genefa Formation; P.P.L. (25X). 


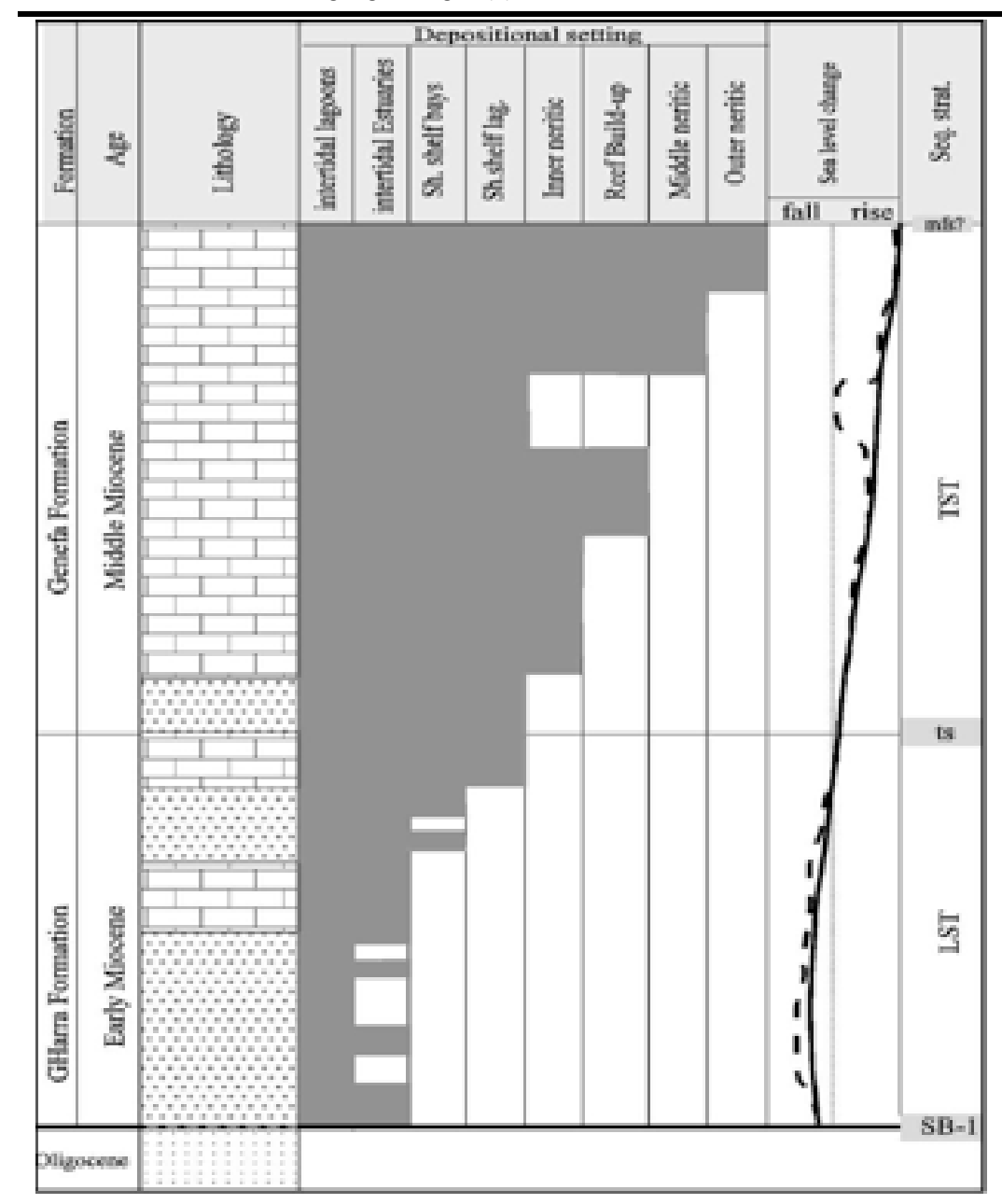

Figure 6. Depositional setting and sea level change of the Miocene platform in the study area. 